\title{
Morpho-physiological and productive indicators of oat under the influence of nanopowders of cobalt and copper trace elements
}

\author{
A.A. Nazarova ${ }^{*}$ \\ Ryazan State Agrotechnological University, Ryazan, Russia
}

\begin{abstract}
Metal nanoparticles are used in agriculture as trace elements for agricultural plants, as growth stimulants, and pesticides. Nanodisperse metals are known to have biological, antioxidant, and enzymatic activity. The article presents the results of research on oat of the "Skakun" variety, conducted in 2014-2017 in the conditions of the Agricultural technology station of RSATU (Ryazan region). The experiment was carried out on gray forest heavy loam soil, in 3 times repetition. Its predecessor is winter wheat. In the experiment, cobalt nanopowder (NP Co) and copper nanopowder (NP Cu) were used with a purity of $99,98 \%$, the size of metal particles was $20-40 \mathrm{~nm}$. The effect of nanopowders of cobalt and copper metals and their combinations on the productive, physiological and biochemical parameters of oat plants in production conditions is shown. The best result was observed when using the preparation with a mixture of cobalt and copper nanoparticles at a concentration of $0.5 \mathrm{~g}$ per average seed rate per hectare - field germination increased by $5.0 \%$, grain yield increased by $15.3 \%$, grain protein content - by $2.0 \%$, fat content - by $0.5 \%$ relative to the control.
\end{abstract}

\section{Introduction}

Today, Russia is a leader in growing oat grain - more than $20 \%$ of the world's gross production. Moreover, various forms of microelements and growth stimulants play an important role in the technology of oat growing [1].

The main function of trace elements is to increase the activity of enzymes and stimulate metabolic processes, which causes intensive growth and development of plants [2]. The use of microfertilizers in the processing of seeds and crops in the technology of grain cultivation contributes to the activation of morpho-physiological processes of plants, improves the quality of grain and increases crops productivity [3].

When studying the methods of microfertilizers application, it was found that in terms of technology, economic and agronomic efficiency, the best results were obtained when using microelements for seed incrustation, planting material processing, as well as when foliar dressing of plants during their growing season [4].

\footnotetext{
${ }^{*}$ Corresponding author: Nanocentr-APK@yandex.ru
} 
The active introduction of nanomaterials containing trace elements in agriculture necessitates a detailed study of new substances in laboratory and field conditions both to determine the most effective nanopreparation, and to establish an their effective combination for inclusion in the production technology of major agricultural crops $[5,6]$.

Nanomaterials and nanotechnologies occupy an increasing place in the development of industry, economy, and agriculture in developed countries [7,8], including in Russia [9]. Increasingly on the world market preparations based on substances in nanostate due to the high demand for environmentally safe and effective agricultural chemicals began to appear. Accordingly, the research of nanomaterials and the formation of scientific ideas about the mechanisms of action of nanoparticles of various nature on plants has become relevant for scientists in the field of agronomy. In addition, it is important to develop and comply with environmental safety standards for the environment and for humans [10]. Nanomaterials have strong biocatalytic properties that depend on the size of nanoparticles, their concentration, and the method of preparation [11].

On the basis of the Nanomaterials and Nanotechnologies Center for Agriculture at the Ryazan SATU named after P.A. Kostychev, studies are being carried out to study the biological activity and safety of nanomaterials of various nature and the development of growth stimulants and micronutrients based on them, taking into account soil, climatic conditions and species characteristics of agricultural crops. Metal nanoparticles are strong biocatalysts due to their structure and specific sizes $(20-40 \mathrm{~nm})$. Their use as microfertilizers-growth stimulators in pre-sowing treatment of agricultural seeds allows to increase the yield and quality of the resulting products $[12,13,14]$.

The aim of the research was to study the effect of optimal concentrations of nanopreparations based on cobalt, copper and their various combinations on the growth, development, productivity and chemical composition of oat of the Skakun variety.

\section{Materials and methods of research}

The research was conducted in 2014-2017 in the laboratory of the Nanomaterials and Nanotechnologies Center for Agriculture and in the conditions of the Agricultural technology station of RSATU. The experiment used cobalt and copper nanopowders, which are fine homogeneous powders of red and dark gray color, respectively, with a particle size of 20-40 nm, without foreign inclusions (purity 99.98\%). Metal nanopowders were produced on the basis of SRTU MISaA, and low-temperature hydrogen reduction of the corresponding metal hydroxides was performed to obtain nanopowders. A suspension of cobalt and copper nanopowders was prepared by dispersing the preparation in distilled water in an ultrasonic bath of the PSB-5735-05 model according to TU 931800-00142720760-96, ultrasonic treatment in an aqueous medium was performed for 20 minutes [15]. 


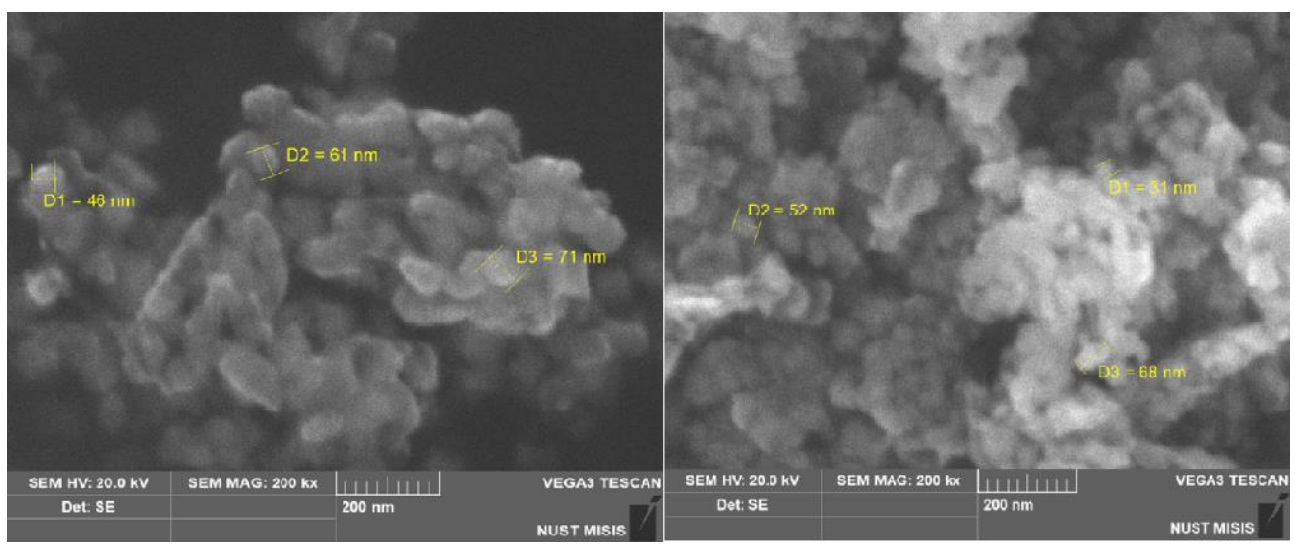

Fig.1. Copper nanoparticles

Suspension of nanopowders was used in pre-sowing seed treatment as the most effective way to influence agricultural crops, determined by previous studies $[16,17]$.

In the experiment, the optimal concentrations of preparations were studied - from 1 to 2 $\mathrm{g}$ of the active substance per hectare of oat seed seeding, since it was in this range of concentrations that an increase in the indicators, growth, development and productivity of other agricultural crops, including grain, was noted [18].

Field tests were carried out on gray forest medium loamy soil, well cultivated, the humus content in the arable layer was $3.4 \%$, the $\mathrm{pH}_{\text {sal }}$ of the soil extract medium was 5.9. Availability of mobile phosphorus $-13.0-14.5 \mathrm{mg} / 100 \mathrm{~g}$ of soil and potassium - 11.8-12.4 $\mathrm{mg} / 100 \mathrm{~g}$ of soil. The soil density is $1.1-1.2 \mathrm{~g} / \mathrm{cm}$. The repetition in the experiment is 3 times, the placement of options is systematic, the area of the plot is 1 ha, the harvesting area is 0.8 ha.

Experiment scheme:

1. Control - seeds were soaked in distilled water for 30 minutes before sowing.

2. NP copper - seeds were soaked in an aqueous solution of the preparation for 30 minutes, the concentration of $1.0 \mathrm{~g}$ per hectare seeding rate $(1.0 \mathrm{~g} / \mathrm{hsr})$.

3. NP cobalt - seeds were soaked for 30 minutes, the preparation consumption is 1.0 $\mathrm{g} / \mathrm{hsr}$.

4. Preparation based on a mixture of cobalt and copper NP - consumption of active substances is only $2.0 \mathrm{~g} / \mathrm{hsr}(1.0 \mathrm{~g} / \mathrm{hsr}$, respectively, NP Cu and NP Co).

5. Preparation based on a mixture of cobalt and copper NP - consumption of active substances is only $1.0 \mathrm{~g} / \mathrm{hsr}(0.5 \mathrm{~g} / \mathrm{hsr}$, respectively, NP Cu and NP Co).

The value of the sum of active temperatures for the growing season is considered to be quite stable for a particular variety, regardless of weather conditions during the growing season. In general, the temperature conditions in 2014-2017 were favorable for oat maturation. The laying of experimental plots, observations, and assessments were carried out in accordance with the methodology "Guidelines for state testing of agricultural crops", determination of protein in oat grain according to GOST 10846-91. Statistical processing of the obtained data was carried out by the Dospekhov's method of dispersion analysis using the Excel 7.0 statistical software package.

\section{Results and their discussion}

At the first stage of research on the effect of biogenic metal nanoparticles of cobalt and copper and their mixtures, field germination, as well as the height and weight of oat plants were studied (table 1). 
Table 1. Morpho-physiological indicators of oat (average for 3 years)

\begin{tabular}{|c|c|c|}
\hline Experiment options & Field germination, $\%$ & Plant height, cm \\
\hline Control & $91.0 \pm 0.5$ & $51.0 \pm 1.49$ \\
\hline $\mathrm{NP} \mathrm{Co} 1.0 \mathrm{~g} / \mathrm{hsr}$ & $92.5 \pm 0.7$ & $50.4 \pm 1.33$ \\
\hline $\mathrm{NP} \mathrm{Cu} 1.0 \mathrm{~g} / \mathrm{hsr}$ & $95.0 \pm 0.3$ & $52.0 \pm 1.12$ \\
\hline $\mathrm{NP} \mathrm{Co}+\mathrm{Cu} 1.0+1.0 \mathrm{~g} / \mathrm{hsr}$ & $94.5 \pm 0.5$ & $55.5 \pm 1.78$ \\
\hline $\mathrm{NP} \mathrm{Co}+\mathrm{Cu} 0.5+0.5 \mathrm{~g} / \mathrm{hsr}$ & $96.0 \pm 0.4$ & $54.3 \pm 1.56$ \\
\hline $\mathrm{LSD} 05$ & 1.7 & 2.41 \\
\hline
\end{tabular}

Treatment of oat seeds with nanopreparations showed the following results: the use of cobalt nanopowder did not show a significant difference with the control, copper nanopowder increased germination by $4.0 \%$, but the best result was shown by nanoparticles of a mixture of copper and cobalt metals, increasing germination at a concentration of 1.0 $\mathrm{g} / \mathrm{hsr}$ - by $5.0 \%$ relative to the control.

It is known that reasonable use of micronutrients subsequently provides a powerful development of root system and leaf area, increases frost and drought tolerance, and increases the strength of chlorophyll protein complex and water-holding capacity. Microelements, acting on physiological processes, increase the activity and synthesis of the most important enzymes, protective functions and resistance of plants to abiotic stresses [4].

Analysis of the duration of both the vegetation and interphase periods of oat showed that copper and cobalt nanopowders did not significantly affect these parameters.

At the leaf-tube formation phase, the height of oat plants was determined, while the difference between the experimental and control plants in height was significant only for a mixture of copper and cobalt nanopowders at a concentration of $2.0 \mathrm{~g} / \mathrm{hsr}(+8.8 \%)$ and 1.0 $\mathrm{g} / \mathrm{hsr}(+6.5 \%$ relative to the control).

At the end of the growing season, the yield and yield structure were determined (table 2 ), as well as the quality indicators of oat grain (table 3 ).

Table 2. Crop structure and yield of "Skakun" oat.

\begin{tabular}{|c|c|c|c|c|c|}
\hline Variant & $\begin{array}{c}\text { Number of } \\
\text { plants } \\
\text { from } 1 \mathrm{~m}^{2}, \\
\text { pcs }\end{array}$ & $\begin{array}{c}\text { Quantity of } \\
\text { grains } \\
\text { in panicle, } \\
\text { pcs }\end{array}$ & $\begin{array}{c}\text { Weight of } \\
\text { grains in } \\
\text { panicle, } \\
\mathrm{g}\end{array}$ & $\begin{array}{c}\text { Weight of } \\
1000 \\
\text { grains, } \\
\mathrm{g}\end{array}$ & $\begin{array}{c}\text { Yield, } \\
\mathrm{c} / \mathrm{ha}\end{array}$ \\
\hline Control & 310 & 31 & 0.85 & 35.22 & 30.1 \\
\hline $\mathrm{NP} \mathrm{Co} 1.0 \mathrm{~g} / \mathrm{hsr}$ & 318 & 34 & 0.94 & 36.85 & 32.6 \\
\hline $\mathrm{NP} \mathrm{Cu} 1.0 \mathrm{~g} / \mathrm{hsr}$ & 322 & 33 & 0.99 & 35.41 & 33.8 \\
\hline $\begin{array}{c}\mathrm{NP} \mathrm{Co}+\mathrm{Cu} \\
1.0+1.0 \mathrm{~g} / \mathrm{hsr}\end{array}$ & 315 & 35 & 1.03 & 36.03 & 31.5 \\
\hline $\begin{array}{c}\mathrm{NP} \mathrm{Co}+\mathrm{Cu} \\
0.5+0.5 \mathrm{~g} / \mathrm{hsr}\end{array}$ & 324 & 35 & 1.07 & 37.94 & 34.7 \\
\hline $\mathrm{LSD} 05$ & & \multicolumn{5}{|l}{} \\
\hline
\end{tabular}

The use of nanopreparations and their various combinations contributed to an increase in indicators: the number of grains in the panicle increased (by $6.5-12.9 \%$ ), the weight of grains in the panicle (by 10.6-25.9\%), the weight of 1000 grains (by 2.3-7.7\%). As a result, the increase in productive indicators led to an increase in the yield of oat seeds: when using a copper nanopowder - by $12.3 \%$, cobalt nanoparticles - by $8.3 \%$, a mixture of $\mathrm{NP} \mathrm{Co}+\mathrm{Cu}$ $1.0 \mathrm{~g} / \mathrm{hsr}$ - by $15.3 \%$ relative to the control, which is the best result in the experiment. And the use of a mixture of NP $\mathrm{Co}+\mathrm{Cu} 2.0 \mathrm{~g} / \mathrm{hsr}$ in pre-sowing treatment did not lead to a significant increase in oat yield.

It is known that elimination of microelement deficiency for oat can increase the grain yield of this crop with more efficient use of mineral fertilizers [19], and the coefficients of 
use of nitrogen, phosphorus and potassium fertilizers increase by 1.5 times or more with reasonable use of microfertilizers [4].

According the Usanova Z.I. and Vasilyeva A.S. [20] comparative analysis of the action of micronutrients in the form of a polymer-chelate complex (Akvadon Micro), humic chelate complex (MAX Super-Humate) and colloid solution of silver nanoparticles (AgBion 2) showed that all kinds of micronutrients was quite effective, helping to improve the safety of the plants before harvest, increasing the photosynthetic potential of the crop (12.3$16.3 \%$ ), reduction of infestation from bacterial and fungal diseases (6.0-13.4\%) increase in grain yield (by 19.4-23.5\%). This is consistent with our results, which showed that foliar dressing with suspensions of microelement nanopowders is ineffective, and the best way to use nanopreparations is pre-sowing soaking of seeds, which helps to increase the oat growth, development and yield.

After harvesting, the ash content and protein and fat content in oat grain were determined in the laboratory (table 3).

Table 3. Che chemical composition of "Skakun" oat grains

\begin{tabular}{|c|c|c|c|}
\hline Variants & $\begin{array}{c}\text { Ash content } \\
\text { of grain, } \%\end{array}$ & $\begin{array}{c}\text { Protein in terms of abs. } \\
\text { dry. sub, } \%\end{array}$ & Fat, \% \\
\hline Control & 2.72 & 9.7 & 3.1 \\
\hline $\mathrm{NP} \mathrm{Co} 1.0 \mathrm{~g} / \mathrm{hsr}$ & 2.83 & 10.1 & 3.3 \\
\hline $\mathrm{NP} \mathrm{Cu} 1.0 \mathrm{~g} / \mathrm{hsr}$ & 2.54 & 10.6 & 3.4 \\
\hline $\mathrm{NP} \mathrm{Co}+\mathrm{Cu} 1.0+1.0 \mathrm{~g} / \mathrm{hsr}$ & 2.68 & 9.9 & 3.3 \\
\hline $\mathrm{NP} \mathrm{Co}+\mathrm{Cu} 0.5+0.5 \mathrm{~g} / \mathrm{hsr}$ & 2.91 & 11.7 & 3.6 \\
\hline $\mathrm{LSD} 05$ & 0.23 & 0.35 & 0.51 \\
\hline
\end{tabular}

Metal nanopowders significantly affected the qualitative composition of the grain, while the ash content of the grain of the experimental and control variants was within the normal range and differed slightly from each other. The dependence of the protein content in the grain on pre-sowing treatment with nanopreparations was noted: in all experimental variants, the protein content was greater than in the control seeds by $0.2-2.0 \%$, the maximum for $\mathrm{NP} \mathrm{Co}+\mathrm{Cu} 1 \mathrm{~g} / \mathrm{hsr}$. Similar changes were observed in the fat content - its level exceeded the control by $0.1-0.5 \%$.

According to Garmash N.Yu. et al. [21] processing of grain crops with microelements leads to both an increase in grain yield by $7.3 \%$ and an increase in the protein content of the grain by $1.4 \%$ compared to the control.

\section{Conclusion}

Thus, field tests of nanopowders of metals-trace elements based on cobalt, copper and their combinations have shown that the use of metal nanoparticles in the technology of cultivation of oat of the Skakun variety contributes to the growth, development, productivity and quality indicators of grain. The most effective result was shown by a preparation based on a mixture of cobalt and copper nanoparticles at a concentration of 1.0 $\mathrm{g}$ per hectare seeding rate ( $\mathrm{NP} \mathrm{Co}+\mathrm{Cu} 0.5+0.5 \mathrm{~g} / \mathrm{hsr}$ ).

\section{References}

1. Promising resource-saving technology for oat production: method, (M.: FSSU "Rosinformagrotech", 2009)

2. B.A. Yagodin, S.P. Torshin, T.M. Udelnova, Biological Sciences, 9, 7-26 (1990) 
3. V.S. Vinogradova, A.A. Martyntseva, S.N. Kazarin Influence of humic and microfertilizers on the yield of spring wheat, 1, 32-34 (2015)

4. I.A. Gaysin, R.N. Sagitova, R.R. Khabibullin, Agrochemical Bulletin, 4, 13-15 (2010)

5. I.G. Golubev, L.A. Nemenushchaya, Nanotechnological developments of agricultural universities (M.: FSBSI "Rosinformagrotech", 2013)

6. V.F. Fedorenko, D.S. Buklagin, I.G. Golubev, Russian nanotechnology, (10)3-4, 126$131(2015)$

7. F. Aslani, S. Bagheri, N.M. Julkapli, A.Sh. Juraimi, F.S.G. Hashemi, A. Bughdadi, The Scientific World Journal, 28 (2014)

8. R. Nair, S.H. Varghese, B.G. Nair, T. Maekawa, Y. Yoshida, D.S. Kumar, Plant Science, 179, 154-163 (2010)

9. V.F. Fedorenko, M.N. Erokhin, V.I. Balabanov, Nanotechnologies and nanomaterials in the agro-industrial complex (Moscow: Rosinformagrotech, 2011)

10. Identification of nanomaterials that pose a potential danger to human health: Methodological recommendations, (MR 1.2.2522-09) (Moscow: Federal Center for Hygiene and Epidemiology of Rospotrebnadzor, 2009)

11. S.D. Polishuk, A.A. Nazarova, M.V. Kutskir, D.G. Churilov, Y.N. Ivanycheva, V.A. Kiryshin, G.I. Churilov, Modern Applied Science, 9(6), 354-364 (2015)

12. S.D. Polischuk, G.I. Churilov, S.N. Borychev, N.V. Byshov, A.A. Nazarova, International Journal Nanotechnology, 15, 4/5, 352-369, (2018) DOI: $10.1504 /$ IJNT.2018.094792

13. S.D. Polischuk, A.A. Nazarova, D.G. Churilov, G.K. Rembalovich, M.Yu. Kostenko, I.S. Arapov, International Journal of Engineering \& Technology, 7(36), 222-230 (2018) DOI:10.14419/ijet.v7i4.36.23749

14. G.I. Churilov, D.G. Churilov, A.A. Nazarova, S.D. Polischuk, V.V. Churilova, S.N. Borychev, N.V. Byshov, International Journal Nanotechnology, 16, 1/2/3, 42-59 (2019) DOI: 10.1504/IJNT.2019.102391

15. L.V. Kovalenko, G.E. Folmanis, Biologically active iron nanopowders, (Moscow: Nauka, 2006)

16. E.I. Kubeev, V.A. Smelik, Technologies and technical means for pre-sowing treatment of agricultural seeds, (Saint Petersburg: SPbSAU, 2011)

17. S.D. Polishchuk, A.A. Nazarova, M.V. Kutskir, G.I. Churilov, Journal of Materials Science and Engineering, 2, 46-54 (2014)

18. O.Yu. Kolmykova, V.V. Churilova, A.A. Nazarova, S.D. Polishchuk, Fruit and berry growing in Russia, XXXXVII, 175-178 (2016)

19. N.V. Samokhvalova, S.F. Spitsina, Bulletin of the Altai State Agrarian University, 4, 89-91 (2004)

20. Z.I. Usanova, A.S. Vasiliev, Achievements of science and technology of the agroindustrial complex, 8, 19-22 (2012)

21. N.Yu. Garmash, G.A. Garmash, A.V. Berestov, G.B. Morozova, Agrochemical Bulletin, 5, 14-16 (2011) 